\title{
Upaya Meningkatkan Literasi Budaya Melalui Gerakan Pramuka dalam Menanamkan Nilai-Nilai Pancasila dan Kesadaran Berkonstitusi Era Teknologi Informasi di Lingkungan SMAN 5 Jambi
}

\author{
Nova Deswita S \\ Guru SMAN 5 Kota Jambi
}

\begin{abstract}
Abstrak: Tujuan dari penelitian ini adalah untuk 1) menyusunan rencana program peningkatan literasi budaya melalui gerakkan pramuka dalam mengimplementasikan nila-nilai pancasila dan kesadaran berkonstitusi era teknologi informasi di lingkungan sekolah; 2) menumbuhkan literasi budaya melalui gerakan pramuka dalam mengimplementasikan nilai-nilai pancasila dan kesadaran berkonstitusi pada era teknologi informasi disekalah; 3) meningkatkan literasi budaya melalui gerakakan pramuka dalam menanamkan nilai-nilai pancasila dan kesadaran berkonstitusi era teknologi informasi dalam pembelajaran; dan 4) meningkatkan literasi budaya pramuka era teknologi informasi dalam mengimplementasikan norma-norma konstitusi dan nilainilai-nilai pancasila pada siswa di sekolah. Metode yang digunakan adalah penelitian kualitatif dengan pendekatan tidak formal karena mengikuti situasi dan kondisi siswa, bertujuan untuk memperoleh gambarani mengenai budaya literasi informasi oleh kalangan pramuka dengan menanamkan nilai-nilai pancasila dan kesadan dalam berkonsatitusi pada era teknologi dan informasi saaat ini. Hasil penelitian ini adalah 1) Penyusunan program pembinaan kesadaran berkonstitusi di sekolah meliputi langkahlangkah: analisis kebutuhan, penyusunan program dan pengesahan, evaluasi dan umpan balik. Melelui penanaman literasi budaya pada kegiatan pramuka di sekolah 2) dalam menumbuhkan literasi budaya melalui gerakkan pamuka di sekolah. Dan juga dalam pembelajaran berkembang "Sangat baik", di mana 10 nilai karakter prioritas 90\% telah menjadi kebiasaan. Kelambatan berkembang pada inisiatif saat diskusi kelompok atau saat presentasi di kelas yang masih mencapai kategori mulai berkembang. 3) Pembangunan kesadaran berkonstitusi dan menumbuhkan nilai-nilai pancasila di lingkungan sekolah berkembang dengan "Baik", di mana $80 \%$ program dapat dijalankan dan 4) Pembangunan kesadaran berkonstitusi di lingkungan masyarakat secara umum berkembang "Sangat baik". Karena dapat juga di sosialisasikan oleh siswa melalu nilai-nilai pramuka, norma-norma konstitusi dan dan gemar melakukan kegiatan meembaca ddengan merevitalisasi perpustakaan melalui literasi budaya.
\end{abstract}

Kata kunci: Literasi budaya, menanamkan nilai-nilai pancasila, kesadaran berkonstitusi

\begin{abstract}
The purpose of this study is to 1) formulate a plan for a program to improve cultural literacy through the movement of scouts in implementing the values of Pancasila and the constitutional awareness of the information technology era in the school environment; 2) fostering cultural literacy through the scouting movement in implementing Pancasila values and constitutional awareness in the era of information technology at school; 3) increase cultural literacy through the movement of scouts in instilling the values of Pancasila and constitutional awareness of the information technology era in learning; and 4) increasing the literacy culture of the information technology scout era in implementing constitutional norms and Pancasila values in students at school. The method used is qualitative research with an informal approach because it follows the situations and conditions of students, aiming to obtain a picture of the culture of information literacy by the scouts by instilling the values of Pancasila and simplicity in constituting in the current era of technology and information. The results of this study are 1) The preparation of constitutional awareness development programs in schools includes the steps: needs analysis, programming and endorsement, evaluation and feedback. Through planting cultural literacy in the activities of scouting in schools 2) in growing cultural literacy through the movement of tutors in schools. And also in learning developing "Very good", where 10 priority character values of 90\% have become a habit. Slowness develops in initiatives during group discussions or when class presentations that reach the category begin to develop. 3) Constitutional awareness building and fostering Pancasila values in a "good" developing school environment, where $80 \%$ of the program can be run and 4) Constitutional awareness building in the general public environment develops "Very good". Because it can also be socialized by students through scouting values, constitutional norms and likes to do reading activities by revitalizing libraries through cultural literacy.
\end{abstract}

Keyword: Cultural literacy, instilling the values of Pancasila, constitutional awareness

\section{PENDAHULUAN}

Perkembangan teknologi informasi membuat siswa dapat mengakses informasi secara mudah dan cepat tanpa batas waktu, siswa tidak terlepas dari teknologi informasi, teknologi yang kearah maya atau internet dapat membuka arus informasi dan komunikasi secara. Perkembangan teknologi dapat mengakibatkan kemunculan fenomena negative yaitu kesalahan disinformasi. Disinformasi merupakan dampak dari pendistribusian secara online didunia maya. Untuk mengatasi fenomena disinformasi diperlukan kemampuan literasi tidak hanya sekedar kemampuan membaca dan menulis tetapi literasi pada era globalisasi informasi saat ini adalah, teknologi, politik, berfikir kritis dan peka terhadap lingkungan sekitar. 
Kemampuan literasi budaya adalah keterampilan prilaku dalam budaya nasional sebagai identitas bangsa, kemampuan bersikap sebagai bagian dari suatu bangsa dalam menangani berbagai permasalahan. Pendidikan literasi sebagai media penanaman nilai nasionalisme dan patriotisme pada siswa melalui program pramuka sebagai penanaman nilai-nilai pancasila dan norma-norma konstitusi dilingkungan sekolah.

Mata pelajaran PPKn sangat besar perannya dalam mewujudkan nilai -nilai pancasila dan norma-norma konsstitusi dalam kehidupan berbangsa dan bernegara khususnya, dilingkungan sekolah , dan dapat meredakan masalah dalam Negara yang mnyangkut masalah kewarganegaraan antara lain masalah-masalah hukum, sosial, budaya, ekonomi dan politik tidak sejalan dengan harapan.

Literasi budaya merupakan kemampuan dalam memahami dan besikap terhadap kebudayaan Indonesia sebagai identitas bangsa oleh karena itu, literasi merupakan kemampuan individu dalam masyarakat dalam bersikap terhadap lingkungan sosialnya sebagai bagian terhadap suatu budaya dan bangsa. Literasi budaya menjadikan hal yang penting untuk di kuasai diabad ke-21.

Pramuka sebagai kegiatan yang selalu dilaksanakan di sekolah-sekolah kita menjadi sangat relevan dalam menyukseskan gerakan penguatan pendidikan karakter dan menumbuhkan norma-norma berkonstitusi, karena pramuka menjadi gerakan karakter bangsa. Dikepramukaan menggunakan 10 pilar yang menjadi kode kehormatan yang menjadi ukuran kesadaran mengenai akhlak yang tersimpan dalam hati dan menyadari harga dirinya dan mejadi standar tingkah laku pramuka di lingkungan sekolah.

Apabila kondisi semacam ini tidak segera diupayakan langkah-langkah perbaikan maka besar kemungkinan akan berpengaruh terhadap lunturnya rasa nasionalisme, hilangnya kepercayaan diri, dan pada puncaknya adalah tercabutnya jati diri bangsa dari akarnya, Permasalahan ini diperparah apabila PPKn yang merupakan pintu utama penanaman nilai-nilai pancasila dan norma-norma konstitusi dilingkungan sekolah masih dibelajarkan dengan mengedepankan substansi tekstual, dan miskin dari substansi kontekstual (skill kewarganegaran). Hal ini sesuai dengan pengakuan 10 siswa yang penulis wawancarai secara terbatas, bahwa selama ini banyak materi substansi nilainilai pancasila dan norma-norma konstitusi masih dipelajari dalam tataran normatif atau tekstual.

Berangkat dari rasa keprihatinan yang mendalam terhadap berbagai permasalahan di atas, penulis berupaya menumbuhkan literasi budaya kepramukaan melalui penanaman norma-norma konstitusi pada era globalisasi di lingkungan sman 5 jambi karena nilai kepramukaan itiu sangat cocok untuk mempersiapkan kaum muda untuk menanggulangi merosotnya karakter anak bangsa karena kegiatan pramuka bersumber dari DASA DARMA PRAMUKA

Berdasarkan penjelasan di atas, adapun yang menjadi tujuan dari penelitian ini adalah untuk 1) menyusunan rencana program peningkatan literasi budaya melalui gerakka pramuka dalam mengimplementasikan nila-nilai pancasila dan kesadaran berkonstitusi era teknologi informasi di lingkungan sekolah; 2) menumbuhkan literasi budaya melalui gerakan pramuka dalam mengimplementasikan nilai-nilai pancasila dan kesadaran berkonstitusi pada era teknologi informasi disekalah; 3) meningkatkan literasi budaya melalui gerakakn pramuka dalam menanamkan nilai-nilai pancasila dan kesadaran berkonstitusi era teknologi informasi dalam pembelajaran; dan 4) meningkatkan literasi budaya pramuka era teknologi informasi dalam mengimplementasikan norma-norma konstitusi dan nilainilai-nilai pancasila pada siswa di sekolah.

\section{Kajian Teoritis}

\section{Meningkatkan literasi budaya melalui gerakan pramuka Era teknologi informasi}

Derasnya informasi yang ada diera informasi manjadikan sebagian sekolah telah bersentuhan dengan teknologi informasi baik yang ada dalam bentuk elektronik multimedia, radio telpon televise hingga internet, namun masalah yang dihadapi saat ini adalah sulitnya membendung derasnya arus informasi, hal yang harus dilakukan adalah dengan maka akan menambah kompetensi yang di miliki siswa dengan mampu mengorganisir dan menggunakan informasi dengan baik dan benar. Literasi dapat memastikan siswa dapat berfikir kritis dan mampu berargument menumbuhkan literasi pada siswa dengan mendidik siswa untuk dapat sepanjang hayat literasi sangat di perlukan dalam berbagai aspek dalam pembelajaran dan akan berlangsung seumur hidsup dengan adanya literasi berfikir kritis terhadap informasi yang diterima.

Literasi merupakan salah satu komponen penting yang harus dimiliki oleh setiap siswa dan berkontribusi dalam mencapai pembelajaran sepanjang hayat, literasi sangat diperlukan dalam segala aspek kehidupan dan berlangsung seumur hidup, dengan adanya literasi maka akan menambah kompetensi yang dimiliki oleh siswa dengan mampu mengevaluasi, mengorganisir. Menggunakan informasi dengan baik dan benar, literasi memastikan individu. Disekolah dapat memiliki kemampuan intelektual untuk dapat berfikir kritis dan inobvatif seta mampu berargumentasi. Bangsa Indonesia merupakan bangsa yang lebih suka menggunakan baharsa lisan. budaya lisan masih sangat melekat pada siswa ketika perkembangan teknologi semakin maju pesat dan tidak terakat bendung seperti sekarang ini, menjadi budaya lisan masyarakat Indonesia bertransformasi menjadi budaya menonton dan melihat. 
Literasi merupakan suatu upaya meningkatkan kesadaran siswa akan pentingnya penggunaan informasi di era teknologi informasi yang ditandai dengan adanya ledakan informasi menjadi komoditas utama di masyarakat dan berpengaruh terhadap siswa disekolah, yang berpotensi menimbulkan permasalahan-permasalahan baru dilingkungan sekolah.

Literasi budaya merupakan kemampuan dalam memehami dan bersikap terhadap kebudayaan Indonesia sebagai identitas bangsa literasi budaya merupeken kemampuan individu dalam masyarakat dan bersikap teiliki kesadaran rhadap lingkungan sosialnya sebagai bagian dari suatu budaya dan bangsa, literasi budaya sangat penting untuk dikuasai diabad ke- 21 oleh setiap orang, terutama generasi muda agar mereka dapat mencintai dan ikut melestarikan kebudayaan Indonesia. Negara memiliki beragam suku bangsa, bahasa/kebiasaan, adat istiadat, kepercayaan, dan lapisan social, turut Negara Indonesia bagian dari dunia turut serta dalam kancah perkembangan dan perubahan global, oleh karena itu kemampuan untuk menerima dan beraptasi dan bersikap secara bijaksana dan cerdas atas keragaman menjadi suatu y7yang penting diabad -21.ini

Kurikulum 2013 disiapkan untuk mencetak generasi yang siap di dalam menghadapai masya depan, untuk itu kurikulum disusun untuk mengantisipasi perkembangan masa depan, pergeseran paradikma belajar abad 21 menjadi pijakan didalam pengembangan 2013. Pramuka akan menjadi kegiatan pramuka wajibbagi peserta didik di sekolah, ada penambahan waktu dari 26 jam menjadi 30 jam seminggu. Ada dua hal yang menjadikan pamuka dijadikan ekstrakurikuler wajib diantarantanya:

1. Dasar jelas yaitu UU no 12 tahun 2010 tentang gerakan pramuka, Kepres no 238 tahun 1961, kepres no 24 tahun2009

2. Pramuka mengajarkan banyak nilai, mulai dari nilai kepemimpinan, kebersamaan, sosial, cinta alam, dan kemandirian

\section{Implementasi kegiatan ekstrakurikuler pramuka}

Kedudukan kegiatan ekstrakurikuler dalam sisstem kurikulum, tidak hanya dipandang sebagai pengisi waktu luang tetapi ditempatkan sebagai komplemen kurikulum yang di rancang secara sistematis yang relevan dalam upaya meningkatkan mutu pendidikan.seluruh aktifitas didedikasikanpada kegiatan kompetensi peserta didik dalam penyelenggaraan ekstrakurikuler untuk mengembangkan kemampuan dan potensi peserta didik. Pelaksanaan pendidikan kepramukaan sebagai ekstrakurikuler wajib disekolah, sejalan dan relevan dengan amanat system pendidikan nasional dalam kurikulum 2013. Petunjuk pelaksaan kegiatan ekstrakurikuler dalam mengimplementasikan kegiatan kepramukaan disekolah adalah:

1. System blok: bentuk kegiatan pendidikan kepramukaan yang dilaksanakan pada awal peserta didik masuk disatuan pendidikan

2. System aktualisasi; adalah bentuk kegiatan pendidikan kepramukaan yang dilaksanakan dengan mengaktualisasikan kompetensi dasar mata pelajaran yang relevan dengan metode dan prinsip dasar kepramukaan

3. Sistem regular: bentuk kegiatan pendidikan kepramukaan yang dilaksanakan pada gugus depan yang da disatuan pendidikan dan merupakan pendidikan kepramukaan secara utuh.

\section{Internalisasi Nilai-nilai karakter}

Strategi yang dilakukan untuk membentuk karakter peserta didik melalui kegiatan eksrtakurikuler pramuka adalah sebagai berikut;

1. Intervensi; adalah bentuk campur tangan yang dilakukan oleh pembimbing ekstrakurikuler pramuka terhadap peserta didik

2. Pemberian keteladanan; kepala sekolah dan guru pembimbing adalah model bagi peserta didik apa saja yang dilakukan banyak ditiru dengan serta merta oleh peserta didik, karena merupakan karakter positif yang mereka miliki sangat bagus jika ditampakkan kepada mereka mau meniru

3. Habituasi/Pembiasan: dengan ungkapan menarik terkait pembantukankarakter peserta didik." Hati-hati dengan kata-katamu" karena itu akan menjadi kebiasaanmu," hati-hati dengan kebiasaanmu karena itu akan menjadi karaktermu“"

4. Mentoring/pendampingan: Pendampingan adalah suatu fasilitas yang diberikan oleh pendamping kegiatan ekstrkurikuler pramuka terhadap berbagai aktifitas yang dilaksanakan oleh peserta didik.

5. Penguatan "penguatan yang diberikan oleh pembimbing ekstrakurikuler pramuka berkhasiat untuk memperkuat prilaku peserta didik.

Gerakan pramuka yang merupakan upaya peran serta anggota gerakan pramuka dalam menumbuhkan literasi sebagai wujud dari penerapan SATYA dan DHARMA PRAMUKA yang telah diwujudkan dengan kegiatan bakti dilingkungan sman 5 jambi..gerakkan pramuka sebagai organisasi pendidikan non formal terpanggil untuk bersamasama siswa disekolah dan pemerintah untuk mengembangkan upaya pengembangan Sumberd daya manusia, dan 
penanggulangan pelestarian lingkungan hidup melalui program pramuka.,melaului Tri bina, yaitu Bina diri, Bina Satuan,Bina sekolah.

Pramuka dalam era teknologi informasi telah berjalan sesuai dengan program pramuka. Gerakan pramuka yang bergerak dalam bidang literasi yang berpegang dalam ajaran founder pendidikan kepanduan, lord baden powell, tentang semangat belajar sepanjang hayat (longlife Learning) dan berbagi pada sesama dan mejunjung semangat keterbukaan dan kesetaraan dengan pandanganbahwa setiap manuasia adalah sama dan tidak ada pilih kasih dan memanggap bahwa setiap manusia adalah memiliki hak yang sama dalam mengakses informasi.

Pada hakekatnya peserta didik didalam pendidikan kepramukaan lebih banyak diperankan sebagai subjek dari pada objek pendidikan. Dengan demikian peran peserta ddiklah yang berperan aktif dalam proses kegiatan sehingga dapat dikatakan yang menjadi pendidik dalam kepramukaan adalah peserta didik sendiri, Pembina pramuka lebih berperan sebagai pembimbing. pendamping dan fasilitator yang senantiasa memberikan motivasi dan stimulasi terhadap konsep kegiatan dan melengkapinya dengan metode yang paling tepat bagi kegiatan tersebut, peserta didik berperan penuh dalam kegiatan pembinaan, perencanaan dan persiapan kegiatan.

\section{Nilai-nilai Pancasila}

Sebagai Dasar Negara, Idiologi bangsa, falsafah bangsa serta pandangan hidup bangsa. Pancasila mengandung nilai dasar. Instrumental, dan praksis. Nilai dasar ini yang disebut Nilai ideal. Nilai ideal inilah yang merupakan hakikat kelima sila pancasila, nilai ideal universal yang didalamnya terkandung cita-cita, tujuan, serta nilai-nilai yang baik dan benar, untuk mengetahu hubungan antara hak dan kewajiban warga Negara dalam nilai ideal pancasila.

\section{Sila Ketuhanan Yang Maha Esa}

Adalah adanya pengakuan dan keyakinan bangsa Indonesia terhadap Tuhan Yang Mha Esa.Nilai Ketuhanan juga memiliki arti kebebasan untuk memeluk agama, menghormati kemerdekaan beragama tidak memaksa atau berlaku diskriminatif antar umat beragama,

\section{Sila Kemanusiaan Yang Adil danbeadab}

. Kemanusiaan Yang adil dan beradab. adalah kesadaran sikap dan prilaku agar sesuai dengan nilai-nilai moral dalam hidup bersama atas dasar tuntutan hati nurani dengan memperlakukan sesuatu hal sebagai mana mestinya.

\section{Sila persatuan Indonesia}

Dalam sila ketiga Persatuan Indonesia ada unsur pemersatu antar warga dengan semangat rela berkorban, selain itu menempatkan kepentingan bangsa dan Negara diatas kepentingan pribadi atau golongan.

\section{Sila Kerakyatan ynag dipimpin oleh hikmah kebijaksanaan dalam permusyawaratan/ perwakilan.}

Dalam sila keempat, Kerakyatan ynag dipimpin oleh hikmah kebijaksanaan dalam permusyawaratan /perwakilan pencerminannya dapat kita lihat dari praktek demokrasi dalam kehidupan berbangsa dan bernegara

\section{Sila keadilan social bagi seluruh rakyat Indonesia}

Dalam sila kelima Keadilan bagi seluruh rakyat Indonesia kita berhak melindungi dan mendapatkan jaminan sosial dengan demikian kita mendapatkan hak milik, mendapatkan pekerjaan dan perlindungan kesehatan.

\section{Menumbuhkan Kesadaran Berkonstitusi di lingkungan sekolah}

Menurut pasal 36UU no 20 tahun 2003 ditetapkan persyaratan pengambangan kurikulum yang harus mengacu kepada standar nasional, dan diarahkan untuk mewujudkan tujuan pendidikan nasional dan dalam rangka Negara Kesatuan Republik Indoesia (NKRI). Diingatkan juga bahwa kurikulum harus memperhatikan kepentingan anak didik, masyarakat dan lingkungan di sekitarnya, agama, kehidupan bangsa dan dunia internasional.

Selanjutnya dalam tujuan Tujuan PPKn di SMA ada empat macam, di antaranya adalah untuk membiasakan siswa mampu (1) berpikir secara kritis, rasional, dan kreatif dalam menanggapi isu kewarganegaraan, dan (2) berpartisipasi secara aktif dan bertanggung jawab, dan bertindak secara cerdas dalam kegiatan bermasyarakat, berbangsa, dan bernegara, serta anti korupsi (Permendiknas No. 22 tahun 2006).

\section{Soft Skills Kesadaran Berkonstitusi}

Dengan mencermati ketujuh prinsip di atas, kita dapat melihat bahwa banyak ruang untuk menanamkan kesadaran berkonstitusi, bukan hanya pada pelajaran Pendidikan Kewarganegaraan (PPKn) namun dapat diintegrasikan dengan berbagai pelajaran lain, khususnya pelajaran-pelajaran yang humaniora. PPKn sebagai pilar dalam pembangunan mental dan perilaku warga negara yang konstitusional memiliki tujuan membentuk warga negara yang ideal, yaitu warga negara yang memiliki keimanan dan ketakwaan terhadap Tuhan Yang Maha Esa, pengetahuan, keterampilan dan nilai-nilai sesuai dengan konsep dan prinsip kewarganegaraan. 
Ketiga komponen ini saling keterkaitan untuk menunjang tujuan tersebut, materi keilmuan PKn harus mencakup pengetahuan (knowlwdge), keterampilan (skills) dan nilai-nilai (values). Dengan menyinergikan ketiga komponen keilmuan dalam PPKn, yaitu pengetahuan, nilai-nilai serta keterampilan kewarganegaraan maka diharapkan akan terbentuk warga negara yang berpengetahuan, terampil dan berkepribadian. Sehubungan dengan hal tersebut, Indra Djati Sidi (2001: 98) juga menekankan orientasi PPKn kepada dua sasaran pokok secara seimbang. Yaitu pertama, meningkatan pengetahuan dan keterampilan siswa tentang etika, moral, dan asas-asas dalam kehidupan berbangsa dan bernegara. Kedua, membentuk sikap, perilaku, dan kepribadian sesuai dengan nilai-nilai luhur Pancasila.

\section{Hard Skills Kesadaran Berkonstitusi}

Nana Syaodih S., dalam Said Hamid Hasan, dkk (2007:27) menyatakan bahwa untuk membantu anak-anak remaja, dalam pengembangan kepribadiannya ke arah integritas secara harmonis, agar dapat menguasai goncangangoncangan psikis menghadapi pengaruh-pengaruh negatif dari lingkungan dibutuhkan bimbingan. Pengembangan diri diprogramkan dalam rangka otonomi sekolah serta memperhatikan keragaman potensi dan kharakteristik siswa. KTSP juga memberikan kewenangan kepada sekolah untuk menentukan materi/kegiatan pengembangan diri sesuai kebutuhan siswa yang harus dilayani. Materi ini bukan termasuk materi pokok kurikulum dan tidak diberi nilai kuantitatif pada rapor. Pelaksanaannya fleksibel namun dinilai setara (equivalent) dengan dua jam pelajaran.

Pengembangan diri memberikan bekal pengalaman praktis secara menarik karena diberikan sesuai kebutuhan siswa. Karena pegalaman praktis, maka pengembangan diri termasuk kategori hard sklills, yaitu tindakan cerdas untuk mewujudnyatakan apa yang telah diketahui dan sudah menjadi keyakinan diri. Jika siswa pernah mempraktikkan suatu peraturan dalam kehidupan nyata maka dia akan mendapatkan pesan yang bermakna (meaningful messages). Pesan yang diperoleh secara bermakna, menurut teori sibernetik akan masuk ke dalam long term memory (memori yang bertahan lama). Apabila hal ini terjadi pada banyak aspek ketatanegaraan yang pernah dilakukan siswa maka kesadaran berkonstitusi akan menjadi "etos kewarganegaraan". Siswa akan selalu bertindak dengan rujukan kerangka aturan hukum yang jelas (konstitusional).

\section{Peranan guru dalam Pembinaan Kesadaran Berkonstitusi}

Ada empat kompetensi guru yang direkomendasikan Asosiasi Lembaga Pendidikan Tenaga Kependidikan Indonesia (ALPTKI), yaitu kompetensi pedagogik, kepribadian, profesional, dan sosial, Azis Mahfuddin (2009: 74). Hal ini sejalan dengan Kepmenpan dan Reformasi Birokrasi No. 16 tahun 2009 tentang jabatan fungsional guru dan angka kreditnya. Secara ringkas empat kompetensi tersebut adalah sebagai berikut ini. Kompetensi pedagogik berkenaan dengan kemampuan mengelola pembelajaran. Kompetensi kepribadian berkenaan dengan dimilikinya kepribadian yang mantap, stabil, dewasa, arif, berwibawa, berakhlak mulia, dan menjadi teladan bagi anak didik. Kompetensi profesional berkenaan dengan kemampuan penguasaan materi pembelajaran secara luas dan mendalam dan dapat membimbing siswa mencapai kompetensi yang diharapkan. Sedangkan kompetensi sosial berkenaan dengan kemampuan berkomunikasi secara efektif dengan peserta didik, sesama pendidik, dan masyarakat sekitar.

Jika dicermati dari keempat kompetensi tersebut, semuanya menuntut peran guru, khususnya guru PPKn untuk mampu memberikan pemahaman tentang (1) hak dan kewajiban sebagai warga negara, (2) pentingnya penegakan hukum dan konstitusi negara, (3) mampu sebagai teladan (profil sebagai warga negara yang sadar hukum), serta (4) berkolaborasi dalam menanamkan kesadaran berkonstitusi dengan guru-guru lainnya.

\section{METODE}

Penulisan ini merupakan penelitian kualitatif yaitu menggunakan pendekatan tidak formal karena mengikuti situasi dan kondisi siswa, bertujuan untuk memperoleh gambarani mengebai budaya literasi informasi oleh kalangan pramuka dengan menanamkan nilai-nilai pancasila dan kesadan dalam berkonsatitusi pada era teknologi dan informasi saaat ini. Menurut moleong (2006:6) penelitian kualitatif adalah penelitian tentang penelitian yang bermaksud memahami tentang fenomena yang dialami subjek penelitian ,secara teori dan secara deskriptif dalam bentu kata-kata dan bahasa. Pembangunan kesadaran berkonstitusi yaitu literasi ng ditulis secara deskriptif kualitatif. Deskripsi kegiatan disajikan berdasarkan dokumentasi program (portofolio), sehingga dapat dikatakan sebagai penelitian dokumentatif.

Studi ini dilskuksn di lakukan di sman 5 jambi karena banyak kegiatan pramuka yang dilakuk telah di wawancarai, penelitian ini dilakukan penulis untuk mendapatkan informasi. Teknik yang digunakan penulis nadalah teknik snowball sampling dilakukan secara berantai dengan meminta informasi pada orang yang telah diwawancaraiih mengutamakan. Sebagai sebuah gerakan moral, pramuka lebihj mengutamakan kebersamaan, kesukarelaan inovasi kreatifitas dan praktek-praktek literasi jalan dengan pendidikan karakter.

Teknik yang dipakai dalam mengambil dan mengolah data penelitian adalah sebagai berikut. Pertama adalah observasi, ata hasil observasi merupakan data kualitatif. Metode observasi yang dilakukan terbatas dan tidak terstruktur-waktu pelaksanaannya menyesuaikan situasi dan kondisi. Data yang terkumpul berupa catatan 
pengamatan terhadap perencanaan, pelaksanaan, dan evaluasi program. Pengamatan dilakukan secara individual maupun kelompok terhadap sikap dan tingkah laku siswa berdasarkan indikator soft skills dan hard skills kesadaran berkonstitusi yang telah ditetapkan. Selanjutkanya dokumentasi, data dokumentasi bersifat kualitatif. Data bersumber dari dokumeni kegiatan dan portofolio kegiatan, dianalisis sebagaimaa data observasi di atas kemudian diintegrasikan kedalam laporan. Data dokumentasi berfungsi terutama untuk memperkuat hasil temuan di lapangan terhadap gejalagejala peristiwa terkait objek perhatian sesuai dengan tujuan penulisan.

Pengolahan data observasi dan dokumentasi dilakukan berdasarkan pendapat Miles \& Huberman (1984: 2122), bahwa analisis data kualitatif dilakukan dengan empat tahap: pengumpulan (data collection period), penyeleksian data (data reduction), pemaparan (data display), dan verifikasi/kesimpulan (conclusion drawing/verification, during and post). Data yang appropriate dengan tujuan penulisan makalah dikumpulkan, diseleksi (reduksi), dipaparkan untuk dicermati, lalu diverifikasi.

\section{HASIL DAN PEMBAHASAN}

\section{Perencanaan Program Pembinaan Kesadaran Berkonstitusi dengan meningkatkan literasi budaya dalam menamnamkan nilai-nilai pancasila}

Kesadaran berkonstitusi memiliki ranah yang sangat luas, karena konstitusi mengatur perikehidupan bernegara yang meliputi berbagai bidang. Suatu program kegiatan harus dirancang, dilaksanakan, dan dievaluasi agar diketahui apakah tujuan dari program tersebut telah secara efektif mencapai sasaran. Perhatian serius harus dicurahkan pada saat perancangan atau desain program agar benar-benar diketahui apakah suatu program mendesak diperlukan. Untuk itulah diperlukan suatu analisis kebutuhan (need assessment) yang melibatkan pihak-pihak terkait.

\section{Analisis kebutuhan}

Meskipun tidak secara formal, analisis kebutuhan yang penulis lakukan adalah saat pembelajaran di kelas: melalui brain storming, dan mengadakan pojok baca identifikasi kasus pada kompetensi dasar yang menuntut pengalaman aplikatif (C3) yaitu skill kewarganegaraan. Kegiatan tersebut memberikan kontribusi berupa masukan pentingnya program pengembangan diri dengan gemar membaca, bela Negara sebagai upaya peningkatan kesadaran berkonstitusi.

\section{Penyusunan dan pengesahan program}

Setelah penulis mengajukan program, kepala sekolah memberikan persetujuan, arahan, dan akomodasi terutama program yang diselenggarakan di dalam pembelajaran dan di lingkungan sekolah bertajuk S2HS.

\section{a. Struktur organisasi kegiatan}

Gambar 1: Struktur organisasi pembinaan "4 Pilar dan PCTA"

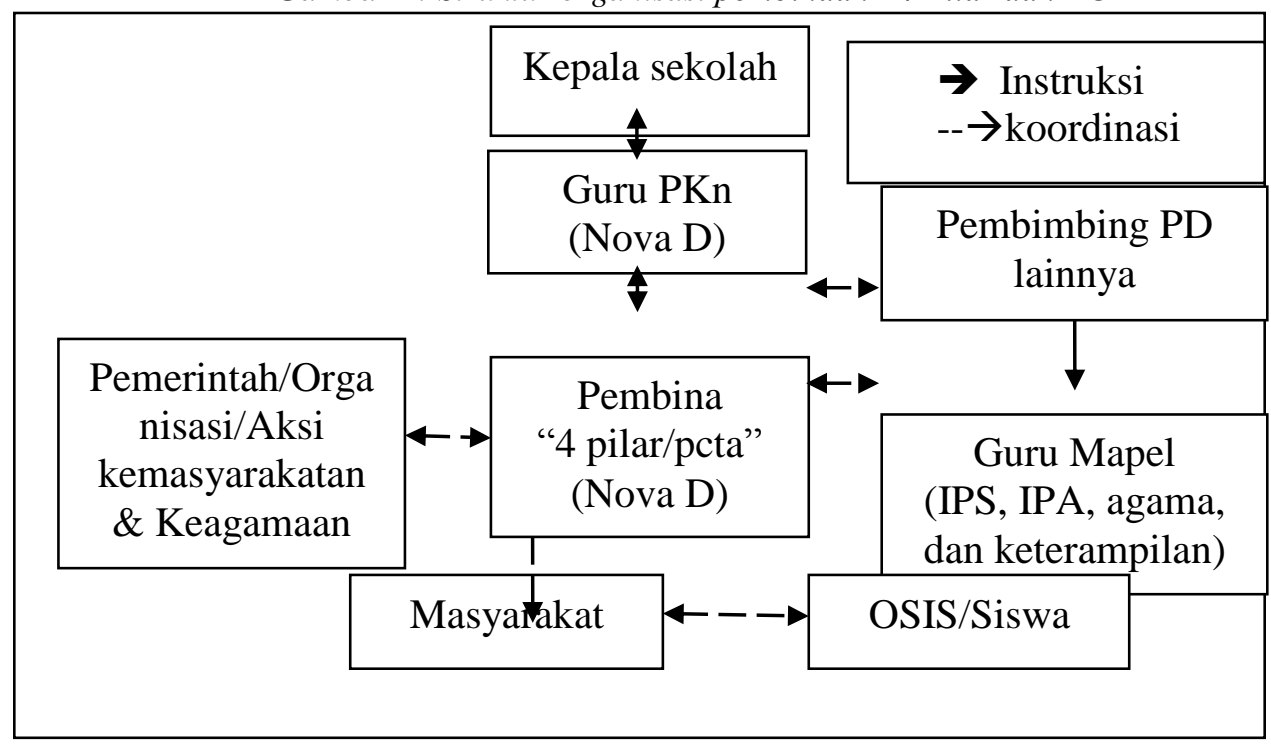

\section{b. Sasaran, metode dan langkah-langkah program kegiatan}

Sasaran kegiatan yaitu upaya peningkatan kesadaran berkonstitusi, melalui berbagai sumber secara kolaboratif, baik soft skill maupun hard skills (S2HS)dalam kegiatan dalam kelas melaui bembiasaan membaca dan kegiatan pramuka, dalam nenanamkan niali-nilai pancasila dan konstitusi . Metode kegiatan berupa kegiatan 
terstruktur (dalam kendali pembimbing) atau kegiatan bebas (disesuaikan kreativitas murid dalam merespon aktivitas di lingkungannya). Program soft skills, yang merupakan peningkatan pengetahuan dan pemahaman nilainilai konstitusi dan membiasakan gremar membaca melalui literasi dilaksanakan melalui pembelajaran PPKn dan keteladanan guru. Sedangkan hard skills dilaksanakan melalui pengembangan diri "4 Pilar/PCTA" yang meliputi beberapa unsur kegiatan di dalamnya.

Evaluasi program dilaksanakan secara periodik melibatkan pihak terkait (Para pembina pengembangan diri, Pembina pramuka, guru mata pelajaran, siswa/OSIS, termasuk tanggapan komite sekolah). Sasaran evaluasi adalah ketercapaian indicator keberhasilan program sebagaimana tersebut di Bab III Bagian D. Umpan balik pelaksanaan program dalam bentuk: 1) Apabila perencanaan kurang efektif maka diadakan analisis kebutuhan yang lebih komprehensif, 2) Apabila diketahui ada peningkatan maka program dikembangkan baik kualitas maupun variasinya. 3) Apabila diketahui terdapat kendala sehingga tidak mengalami peningkatan maka kegiatan dilakukan dengan alternatif metode lain setelah berkoordinasi dengan pihak terkait dan mengetahui kendalanya secara jelas (analisis kebutuhan dan karakteristik sasaran program diperbaharui)

\section{Pengintegrasian nilai Pancasila ke dalam pembelajaran}

Sebagai guru PPKn dalam pembangunan kesadaran berkonstitusi melalui pembelajaran membaca dan menulis melalui gerakan literasai budaya dan merupakan sasaran utama. Kendali program pembangunan adalah nilai-nilai Pancasila. Sebab nilai-nilai dapat diintegrasikan ke dalam kurikulum, budaya sekolah, dan ekstrakurikuler. Usaha membangun kesadaran berkonstitusi di dalam pembelajaran yaitu melalui pengetahuan, sikap, dan skill kewarganegaraan yang baik.

\section{Perencanaan Pembelajaran}

Langkah-langkah pengintegrasian nilai-nilai Pancasila delksanakan program gemar membaca melalui literasi budaya dalam menumbuhkan kesadaran berkonstutusike dalam perencanaan pembelajaran adalah sebagai berikut: 1) Menganalisis KI/KD, 2) Kegiatan pembelajaran, 3) Menggunakan pendekatan cooperatif learning, 4) Mendeskripsikan nilai-nilai pancasila, 5) Mengamati nilai-nilai pancasila.

\section{Implementasi Nilai-nilai pancasila dalam proses pembelajaran}

Penulis senantiasa berusaha memilih pendekatan pembelajaran kooperatif dengan berbagai strategi yang membuat siswa aktif dan mengasah skill kewarganegaraan. Usaha untuk meningkatkan kesadaran konstitusi dengan metode simulasi, dan pembiasan membaca juga dilaksanakan, baik melalui pembelajaran maupun kegiatan nyata (penugasan). Melalui pembelajaran, khusus pada kompetensi dasar (KD) yang bersifat aplikatif penulis menerapkan beberapa metode pembelajaran yang efektive.

Tabel 1: Tingkat keberhasilan program melalui pembelajaran

\begin{tabular}{|c|c|c|c|c|}
\hline $\begin{array}{lr}\text { Nilai } & \text { Karakter } \\
\text { Periode/Keberhasilannya }\end{array}$ & Konstitusi/ & $\begin{array}{l}\text { Jan-Des } \\
2017\end{array}$ & $\begin{array}{l}\text { Jan-Des } \\
2018\end{array}$ & $\begin{array}{l}\text { Jan-Jul } \\
2019\end{array}$ \\
\hline Kerjasama dalam kelompok & & MT & MB & MK \\
\hline Tanggung jawab menyelesaikan tugas & & MB & MK & MK \\
\hline Disiplin dalam penggunaan waktu & & MB & MK & MK \\
\hline Taat aturan dalam diskusi/belajar & & MK & MK & MK \\
\hline Kebersamaan dalam memecahkan mslh & & MT & $\mathrm{MB}$ & MK \\
\hline Inisiatif dalam diskusi/bekerja kelompok & & MT & MB & MB \\
\hline Berpendapat/menerima pndpt secara santun & & MK & MK & MK \\
\hline Kerja keras dalam mencari sumber belajar & & MT & MK & MK \\
\hline Religius (berdoa awal/akhir pembelajaran) & & MK & MK & MK \\
\hline Cinta tanah air (bangga sbg bangsa Ind) & & MB & MK & MK \\
\hline Persentase (\%) Keberhasilan & MT & 40,00 & 0 & 0 \\
\hline MT=mulai tampak, MB=Mulai berkembang, & MB & 30,00 & 30,00 & 10,00 \\
\hline MK=menjadi kebiasaan (membudaya) & MK & 30,00 & $\mathbf{7 0 , 0 0}$ & 90,00 \\
\hline
\end{tabular}

(Sumber: Dok. pembelajaran PPKn (Rata-rata kelas nilai afektif/Pendikar)

Hasil evaluasi program antara periode 2017-2018 adalah sebagaimana tabel 2. Berdasarkan table 2 di atas, tingkat keberhasilan program (MK) terus mengalami peningkatan dari periode 2017 sampai 2018. Pada tahu 2018 tingkat keberhasilan 30\% (kurang), periode 2018 mencapai 70\% (cukup), dan pada pertengahan periode 2019 sudah mencapai 90,00\% (Sangat baik). Kelambatan berkembang pada inisiatif saat diskusi kelompok atau saat presentasi di 
Nova Deswita S, Upaya Meningkatkan Literasi Budaya Melalui Gerakan Pramuka dalam Menanamkan Nilai-Nilai Pancasila dan Kesadaran Berkonstitusi Era Teknologi Informasi di Lingkungan SMAN 5 Jambi

kelas yang masih mencapai kategori MB (mulai berkembang). Kemampuan inisiatif memag memerlukan latihanlatihan dan peningkatan wawasan.

\section{Pembangunan Kesadaran Berkonstitusi di Lingkungan Sekolah}

"4 PILAR /PCTA" adalah nama salah satu program pengembangan diri SMAN 5 Jambi. Aspek bela negara memiliki cakupan yang sangat luas. Sebagai contoh hasil pengembangan diri "4 PILAR/PCTA", siswa telah banyak berpartisipasi di luar sekolah, baik dalam bentuk kegiatan keagamaan (di Mesjid), masyarakat (bhakti sosial dan diskusi bidang hukum dan demokrasi). Deskripsi singkat program pengembangan diri "4 PILAR/PCTA" SMAN 5 Jambi adalah sebagai berikut.

\section{Program Cinta Indonesia}

Program peningkatan "Cinta tanah air Indonesia" litersi budaya, dalam pengembangan diri dilakukan dengan metode portofolio: (a) mendiskusikan kondisi wilayah setempat: mencermati potensi ancaman, tantangan, hambatan dan gangguan (ATHG), (b) menyusun alternatif penangkal ATHG tersebut, dan (c) memilih, melaksanakan dan melaporkan kegiatan tersebut di sekolah dan masyarakat (upacara bendera, keamanan sekolah, Latihan Dasar Kepemimpinan (LDK), dan kegiatan masyarakat).

\section{Pelestarian lingkungan hidup (Lestari)}

Pelestarian lingkungan hidup, dimulai dari pemberdayaan 7K, khususnya "kerindangan". Mengingat keberadaan sekolah di tengah-tengah keramaian maka dibentuk kelompok ilmiah remaja (KIR) "Cycloops Care". Kesadaran lingkungan dapat diwujudkan dalam skala mikro, seperti peduli kebersihan "sambil jalan angkat sampah" (Langkah), program satu anak satu pohon (Sason), sekitar sekolah. Yang di tandai bahwa sman 5 adalah mendapat juara Ipada lss lomba sekolah sehat tingkat kota jambi.

\section{Program "toleransi"}

Dalam hal ini kegiatan "4 pilar" dapat berkolaborasi dengan berbagai kegiatan pramuka melalui aksi sosial yang ada. Kegiatan yang senantiasa dilaksanakan yaitu pengumpulan bantuan untuk korban bencana , pengumpulan seragam layak pakai untuk siswa di daerah terpencil, serta berpatisipasi dalam kegiatan keagamaan lainnya. Kesadaran akan kerukunan hidup serta kesetiakawanan sosial yang meningkat, membuat Jambi menjadi contoh "masyarakat madani": multi etnis, agama, ras, golongan namun hidup berdampingan secara damai. Dengan melibatkan siswa ke dalam kegiatan sosial dan keagamaan tersebut maka akan tumbuh kesadaran bangga akan pluralisme Indonesia di dalam ikatan NKRI, Pancasila dan UUD 1945.

\section{Program "Sadarkum"}

Aspek 7K, khususnya "keamanan dan ketertiban" merupakan starting point dalam pembentukan kesadaran hukum mulai skala kecil. Ketertiban dan kedisiplinan belajar merupakan tujuan yang dapat dirasakan manfaatnya oleh siswa. Menghilangkan potensi terjadinya perkelahian pelajar, membuat dan menegakkan tata tertib sekolah, pembinaan kesopanan dan rasa hormat yang muda kepada yang tua merupakan program kesadaran hukum yang "membumi" di SMAN 5 Jambi. Bahkan ketertiban dan kedisiplinan menjadi "budaya sekolah" sehingga mendapatkan penghargaan di atas.

Kesadaran berkonstitusi dalam kehidupan demokrasi juga dilaksanakan secara integratif dalam kehidupan sekolah. Suasana keterbukaan dewan guru, tata usaha dan kepala sekolah mempermudah pengembangan kehidupan demokrasi. Prinsip yang dikembangkan adalah "keteladanan". Demokrasi adalah ibarat "kran" yang mengalirkan aspirasi dari berbagai arah untuk menyuburkan segala kegiatan dan membuat kehidupan sekolah menjadi "rindang". Terkait dengan kesadaran berkonstitusi, siswa SMAN 5 Jambi mengikuti Lomba Cerdas Cermat UUD 1945 sebagai juara 2 kota Jambi, .lomba olimpiade konstitusi juara 4 besar se propinsi jambi yang dihadiri oleh ketua mahkamah konstitusi di laksanakan di universitas jambi Pada saat itu penulis adalah sebagai guru pembimbingnya.

\section{Keteladanan sebagai kunci utama program}

Untuk saat ini keteladanan adalah kunci utama dalam mengembangkan kesadaran berkonstitusi. Keteladanan dalam budaya berprestasi telah penulis lakukan di tengah-tengan warga sekolah. Sehingga hal ini dapat membangun struktur impian (Visi dan Misi sekolah) yang terlihat sulit diwujudkan, terutama dalam prestasi. Sebagai guru, Dalam hal ini semua warga sekolah tahu bahwa prestasi harus diraih dengan kerja keras, disiplin, bertanggung jawab, menghargai prestasi, tepat waktu, saling menghormati, kesetiakawanan, memiliki sifat kejuangan dan cinta sekolah sebagai perwujudan cinta tanah air. Hal tersebut bisa dilihat pada tabel di bawah ini: 
Nova Deswita S, Upaya Meningkatkan Literasi Budaya Melalui Gerakan Pramuka dalam Menanamkan Nilai-Nilai Pancasila dan Kesadaran Berkonstitusi Era Teknologi Informasi di Lingkungan SMAN 5 Jambi

Tabel 2. Pembangunan kesadaran berkonstitusi di lingkungan sekolah

\begin{tabular}{|c|c|c|c|c|}
\hline $\begin{array}{l}\text { Nilai } \quad \text { Karakter } \\
\text { Periode/Keberhasilannya }\end{array}$ & Konstitusi/ & $\begin{array}{l}\text { Jan-Des } \\
2017\end{array}$ & $\begin{array}{l}\text { Jan-Des } \\
2018\end{array}$ & $\begin{array}{l}\text { Jan-Jul } \\
2019\end{array}$ \\
\hline Cinta tanah air (aman, tertib) & & MB & MK & MK \\
\hline Pelestarian lingkungan (bersih, indah) & & MT & MB & MK \\
\hline Kerukunan (tidak tawuran, kebersamaan) & & MB & MK & MK \\
\hline Sadar hukum (taat aturan, disiplin, sanksi) & & MK & MK & MK \\
\hline Keteladanan (prestasi warga sekolah) & & MT & MB & MB \\
\hline Persentase (\%) Keberhasilan & MT & 40,00 & 0 & 0 \\
\hline MT=mulai tampak, MB=Mulai & MB & 40,00 & 40,00 & 20,00 \\
\hline $\begin{array}{l}\text { berkembang, MK=menjadi kebiasaan } \\
\text { (membudaya) }\end{array}$ & MK & 20,00 & 60,00 & 80,00 \\
\hline
\end{tabular}

(Sumber: Dok. Program Menuju Adi Wiyata (Kultur sekolah)

\section{Pembangunan Kesadaran Berkonstitusi di Lingkungan Masyarakat}

Program kesadaran berkonstitusi yag melibatkan masyarakat terdiri dua jalur, yaitu (1) komite sekolah dan (2) di tempat tinggal penulis di komplek perumahan amuntai blok d2 no 12 jambi

\section{Melalui Komite Sekolah}

Penulis bukan pengurus komite sekolah, namun sering dilibatkan dalam kegiatan komite, karena penulis ada;lah wakil kepala sekolah bidang humas yang selalu bekerja sama dengan komite sekolah, misalnya menyampaikan motivasi pentingnya pendidikan, pemecahan masalah anak, keamanan siswa dan lingkungan sekolah sebagai wiyata madala.

\section{Melalui Pengajian di Kampung}

Penulis sering menyisipkan pesan bersikap positif dalam menaggapi isu kewarganegaraan (politik, pendidikan, toleransi, taat hukum, pelestarian lingkungan, pentingnya musyawarah, dan persatuan). Untuk itu penulis harus menjadi figur teladan bagi masyarakat sekitarnya dalam pengamalan dan ketaatan terhadap hukum, kerukunan, menjaga lingkungan, dengan memnanamkan nilai-nilai pancasila dan membangkitkan kesadaran berkonstitusi.

\section{SIMPULAN}

Adapun kesimpulan yang dapat diambil dari penulisan ini adalah sebagai berikut:

1. Penyusunan program pembinaan kesadaran berkonstitusi di sekolah meliputi langkah-langkah: analisis kebutuhan, penyusunan program dan pengesahan, evaluasi dan umpan balik. Melelui penanaman literasi budaya pada lpada kegiatan pramuka disekolah

2. Pembangunan kesadaran berkonstitusi melalui implementasi nilai-nilai pancasila dalam menumbuhkan literasi budaya melalui gerakkan pamuka di sekolah. Dan juga dalam pembelajaran berkembang "Sangat baik", di mana 10 nilai karakter prioritas $90 \%$ telah menjadi kebiasaan (MK). Kelambatan berkembang pada inisiatif saat diskusi kelompok atau saat presentasi di kelas yang masih mencapai kategori MB (mulai berkembang). Kemampuan inisiatif memang memerlukan latihan-latihan dan peningkatan wawasan.

3. Pembangunan kesadaran berkonstitusi dan menumbuhkan nilai-nilai pancasila di lingkungan sekolah berkembang dengan "Baik", di mana 80\% program dapat dijalankan. Kelambatan berkembang pada keteladanan dan usaha pelestarian lingkungan dengan gerakan literasi budaya melalui gerakan pramuka

4. Pembangunan kesadaran berkonstitusi di lingkungan masyarakat secara umum berkembang "Sangat baik". Karena dapat juga di sosialisasikan oleh siswa melalu nilai-nilai pramuka, norma-norma konstitusi dan dan gemar melakukan kegiatan meembaca ddengan merevitalisasi perpustakaan lmelalui literasi budaya.

berikut:

Adapun saran-saran yang dapat diberikan berdasarkan penelitian yang telah dilakukan diantaranya sebagai

1. Kepada warga sekolah hendaknya meningkatkan keteladanan, bagi siswa terutama dalam mewujudkan kultur sekolah yang taat aturan, misalnya dalam menerapkan kawasan sekolah sebagai kawasan "bebas asap rokok" dan "wajib ambil sampah" serta sholat zuhur berjamaah di masjid sekolah..

2. Kepada sekolah, hendaknya memprogramkan dalam RKAS setiap tahun (bertahap) pengadaan revitalisasi perpustakaan melalui literasi budaya sehingga program gemar membaca tumbuh dan berkembang dilingkunag sekolah ,dan program memungut sampah agar menjadi sekolah yang bersih,dan hijau. sehingga program satu anak membawa satu jenis tanaman dapat berjalan baik. Hal ini berimbas kepada pembiasaan tanggung jawab, kerja keras, kreatif, produktif, dan cinta tanah air bagi diri siswa yang didapat dari penanaman nilai-nilai pancasila dan gerakan pramuka 
3. Kepada pihak yang berwajib, hendaknya mendukung program "gerakan literasi dengan menumbuhkan gemar membaca melalui penanaman nilai-nilai pancasila dengan kesadaran berkonstitusi, dkeguiatan pramuka di liongkungan sekolah, serta bebas narkoba" di Kota Jambi

4. Kepada pemerintah Kota Jambi, hendaknya bekerja sama dengan Ketua RT/RW dalam mewujudkan masyarakat Kota Jambi yang Beriman (Bersih, Indah, Nyaman, dan Aman).

5. Kepada Pihak Kepolisian, hendaknya mengadakan penyuluhan dalam pemberian materi melalui BNN tentang sekolah bebas narkoba di contohkan dengan penanaman nilai-nilai pramuka dilingkungan sekolah

6. Dengan literasi budaya melalui gerakan pramuka di sekolah, siswa sdapat meningkatkan nilai-nilai yang ada dalam dasa darma pramuka dan dalam sila-sila pancasila

\section{DAFTAR PUSTAKA}

Ahmad A, perkembangan media online dan fenomena disinformasi anamisis sebuah situs isla (2013) $\mathrm{htt} /$ doi.org/10.30818/jpkm2013.1160305

Azis Mahfuddin. (2009). Profesionalisme jabatan guru di era globalisasi. Bandung: Rizqi Press.

Depdiknas. (2013). Kumpulan Permendiknas tentang Standar Nasional Pendidikan (SNP) dan panduan k-13

Indra Djati Sidi. (2001). Menuju masyarakat belajar: menggagas paradigma baru pendidikan. Jakarta: Paramadina.

Kementrian pendidikan dan kebudayaan (2017) mentri pendukung literasi nasional.redrieved,novewmber 2018.htt/gln.kemdikbud.go.id/glnsite/wp

Kwartir Nasional gerakan Pramuka (2011) Mahir dasar pemnina Pramuka. Jakarta: Joko mursitho

Miles, M.B. \& Huberman, A.M. (1984). Qualitative data analysis: a source book of new methods. California: Sage Publication Inc.

Parno, 2017. mendorong gerakan literasi untuk masa depan pendidikan. https//sewod.com/pendidikan/pendorong gerakan literasi untuk masa depan-pendidikan.

Said Hamid Hasan. (2007). Inovasi Kurikulum (Jurnal Himpunan Pengembang Kurikulum Indonesia). Bandung: HIPKIN.

Sumadi Soeryabrata. (2002). Metodologi Penelitian. Jakarta: PT. Raja Grafindo Persada.

Suwarno, H. 2017. Abad 21. http//guru inspiratif.com./literasi abad 2.

Yuyus kardiman( 2018).Pendidikan Pancasila dan kewarganegaraan revisi. Jakarta: Erlangga 